\title{
A Survey of Corporate Bankruptcy Reforms: Lessons to Be Learnt for Worldwide Good Practices
}

\author{
Afef BOUGHANMI \\ University of Lorraine (IUP Finance), BETA-CNRS, 13 place Carnot - C0 n² 26 - 54035 NANCY CEDEX \\ Nirjhar NIGAM \\ ICN Business School, CEREFIGE, LARGE, 3 Place Edouard Branly, Metz, France
}

\section{Abstract}

Recent years have witnessed a phenomenal upsurge in the number of corporate bankruptcies. The vulnerabilities which were lying dormant within contemporary bankruptcy regimes suddenly became apparent, causing concerns within the international corporate community. Consequently, researchers, practitioners and policy makers from all over the world got actively engaged in emphasizing the importance of efficient bankruptcy reforms for promoting rescue culture. The primary objective of an insolvency framework should be to provide quick, transparent and cost effective solutions for the resolution of financial distress and promotion of a synergetic environment conducive for the proliferation of healthy debt repayment practices, increased trust factors between creditors and debtors and a better survival rate for viable businesses. In this paper we present a qualitative review of various insolvency reforms introduced in nearly 189 economies over a decade (2005 to 2015), for the efficient resolution of financial distress. For data collection purpose, we use World Bank Database from Doing Business Reports (2005-2015). We provide latest data on the recovery rates, costs, time for resolution based on recent statistics (until June 2015). Finally, we present a list of most popular reforms in bankruptcy and also when possible the effect of their application. This is one of the comprehensive surveys on worldwide corporate bankruptcy reforms. *

Keywords: Insolvency Law, Corporate Bankruptcy Law, Liquidation, Reorganization, Bankruptcy cost, recovery rates.

JEL classification: G33, K22

\section{Introduction}

Over the year, Bankruptcy has evolved from an abominable procedure to much more humane process. In ancient Rome, bankruptcy was treated with utmost disdain and its consequences were horrendous: slavery or being shredded to pieces. The scenario in England was a bit milder with punitive measures such as prison sentences, defaulters chained to pillars and on a harsh day, their ears chopped off. This indeed paints a gross and grotesque picture of what bankruptcy was in yesteryears and how laws have gradually evolved to allow for a more humane approach pertaining such matters. In 1732, England passed the first modern bankruptcy law paving way for the United States to emulate it and form its first bankruptcy law in 1800. Prominent European countries such as France, Germany and Spain followed suit and formulated their own inceptive bankruptcy laws. This marked a shift in perception towards bankruptcy from an incorrigible affliction to a resolvable condition by liquidating financially distressed firms and allocating their remaining assets amongst creditors. In 1914, Austria developed an elementary procedure for reorganizing the debt of a bankrupt company and reviving its business activities but it did not receive much attention and adoption. However, it sparked the development of similar mechanisms in various European countries like Spain in 1922, South Africa in 1926 and France, Germany, Netherlands, Belgium and the United States during the 1930's. And the adoption of Chapter 11 by the United States in its bankruptcy code, in 1978, marked the arrival of the first modern reorganization procedure. This was followed by a series of bankruptcy reforms across major economies of the world, over the next 25 years. Some notable mentions are Italy (1979), France (1985), United Kingdom (1986), New Zealand (1989), Australia and Canada (1972), Germany (1994, 1999), Sweden (1996) and Japan and Mexico (2000). This momentum carried on and by mid 2003, almost every nation included in the Doing Business sample was

\footnotetext{
* We are grateful for comments received from reviewers and the members of Cerefige, Beta and Large labs. Any remaining errors are entirely our responsibility.
} 
equipped with some form of bankruptcy law. Cambodia was an exception, however. It is now widely being acknowledged that robust and efficient bankruptcy laws are essential for inhibiting or preventing altogether, financial and economical instabilities, which may arise, due to constant flux within our global business and economic landscape. The key objectives of such regimes is the minimization of damages while maximizing the efficiency of reallocating leftover resources within the bankrupt organization, amongst all the affected parties, in a harmonious manner. As compared to ancient times when punishments for failing in business invited loathful and severe consequences, these modern bankruptcy regimes strive to balance the equation to achieve and maintain a thriving economic community by encouraging entrepreneurs to take calculated risks and should anything go wrong, assure the managers that, if acted in time, measures are in place to revive all possible chances of recovery for all the parties involved.

Today's bankruptcy regimes differ enormously in their efficiency and use and Bankruptcy is still in its infancy in many countries, and reform continues even in the best-performing jurisdictions.

With this objective, we will try to make a survey of most important bankruptcy reforms introduced by nearly 189 economies.

The paper is organized as follows: Section 1 explains the goals of Bankruptcy law, Section 2 provides the effects of good bankruptcy laws, in Section 3 we provide a survey of bankruptcy reforms and lessons to be learned from worldwide good practices, in Section 4 we explore some reforms that are still not popular but can have good impact in future and lastly we recommend some reforms that need to be reconsidered and we conclude in Section 5.

\section{What should be the Goals of Bankruptcy Law?}

It is difficult to design an optimal bankruptcy law but it should aim at achieving at least the following goals:

Filtering: Whenever default is triggered, managers and the bankruptcy officials are left with determining the market value of the firm. This is a crucial decision based upon which future course of action (liquidation or reorganization) for the defaulted firm is decided. Thus, filtering of viable and nonviable firms is inherent for any bankruptcy law ${ }^{1}$. This filtering should be accurate otherwise efficient firms will be liquidated and inefficient firms allowed to continue which would result in further economic losses.

Maximization of the Value of the Firm: A bankruptcy process should maximize the total value of the firm's assets to be divided among various stakeholders. Consequently, firms may be reorganized, sold as going concern, liquidated piecemeal or shut down. Whatever procedure is chosen, underlying principle should remain the same: maximization of the total value of the firm available to stakeholders.

Provide Good Incentives Before Default: A good bankruptcy regime should be able to maximize the value of the firm long before any signs of default are evident. This means providing right incentives to the debtors and the managers long before bankruptcy. Often the investment and financial decisions of a firm are taken much before any sign of default surfaces at the horizon. By monitoring the activities of debtors and keeping their risk taking activities under control, bankruptcy laws can ex ante protect the creditor claims. It must be able to sanction the faulty management which destroys the value of the company by undertaking too risky projects and putting the creditor's money at stake.

Preservation of the Bonding Role of the Debt: Absolute priority means that senior creditors must be paid in full before any proceeds are distributed among junior creditors and stockholders. It should preserve the bonding role of the debt and keep a check on the entrepreneur's risk taking abilities. This motivates the lenders to finance the companies as they feel confident that contractual agreements entered with the company will be honored even when company defaults. Every bankruptcy law provides for absolute priority order but how far it is followed still remains a question. Moreover, there is still a big debate among the academics about efficiency effects of this feature ${ }^{2}$. In practice we observe quite a lot of deviations from APR.

\footnotetext{
${ }^{1}$ Fisher and Martel (2004), study a sample of 303 Canadian firms in reorganization during 1977-1988. They find the type I errors (allowing a nonviable firm to continue) are likely to have four times more than the type II errors (shutting down a viable firm). ${ }^{2}$ For some academics deviations from APR is supposed to be beneficial [Bebchuk and Picker (1993), Berkovitch, Israel, and Zender (1997, 1998), Baird (1991), Gertner and Scharfstein (1991), White (1989)]. While others believe adherence to APR increases efficiency [Jackson (1986), Hart (1995), Bebchuk (2002)] 
Protecting the Interests of the Residual Claimants: One of the reasons companies fall into distress is often attributed to the managerial behavior and excessive risk taking. Bankruptcy law must ensure transfer of control to the creditors who are directly affected by the outcome of bankruptcy and not to people who have been responsible for the onset of default (managers). The future of the firm should be decided by the residual claimants because their lives are directly impacted by bankruptcy. This process ensures that the outcomes are favorably inclined towards the stakeholders as well as in the best interest of the firm.

Saving Procedural Costs: Bankruptcy process should be easy, flexible and should provide quick and efficient solutions to the firm. As time is considered to be directly proportional to the cost of the procedure, adhering to a strict deadline, defined by laws, ensures a cost effective outcome. This is necessary so that stakeholders receive the maximum value out of the firm's assets and that the value of estate is not lost in lengthy and cumbersome bankruptcy proceedings. In US, these costs are found to consume substantial part of bankruptcy estate (Altman, 1984; Altman and Vanderhoof, 1994).

Finding the Optimal Tradeoff between Transparency and Confidentiality: Asymmetry of information between the creditors and debtors is one of the biggest obstacles in the way of resolving distress. An efficient bankruptcy regime should transfer credible information to all the stakeholders of the company. This information should be trustworthy and credible ${ }^{1}$ so that stakeholders can make decisions. However, in bankruptcy, information is often made public and can trigger panic situations whereas confidentiality prevents panics. Chatterjee, Dhillon, and Ramirez (1995) show less negative abnormal returns for announcement of workout than Chapter 11 filings. Gilson, John, and Lang (1990) further add that stocks returns are more negative for firms that subsequently file for Chapter 11.

The effectiveness of bankruptcy regime as investigated by the researchers is often measured by two of its complementary aspects: ex-Post and ex-Ante Efficiency (Hart, 1995). A procedure is said to be ex-post efficient if it maximizes the value of the distressed firm, involves low bankruptcy costs and transfers the control to the creditors. This signifies that law must choose the procedure that makes the best possible use of the firm's assets keeping in mind the rights of all stakeholders while deciding the priority order for distribution. The ex-post efficiency is determined by two important features of bankruptcy law. First, credible information about the debtor and its company is made available and is duly disseminated to other concerned parties so that they are able to make correct assessments. Second, it aids in decision making process by coordinating the actions of the creditors. Both these factors play an important role in maximizing the value of the firm and also in determining ex-post efficiency.

Ex-ante efficiency analyses the effects of legal mechanism on the incentives of involved parties before the firm enters into default, even before any signs of financial distress are evident at the time of making contracts and taking financing decisions. This is the reason why bankruptcy law has been considered a significant factor in determining capital structure of the firm and major financing decisions. The bankruptcy procedures have an impact on the access of credit long before any signs of default are visible. If the creditors believe that they are less protected in the event of bankruptcy, they would increase the cost of credit or refuse it all together. In order to allow easy credit flow, collective procedures must protect the rights of the creditors and allow them to monitor the activities of the borrowers. Thus, bankruptcy procedures are ex ante efficient if they allow the company to undertake profitable projects and turn down projects that involve too much of a risk and at the same time keep a check on reckless risk taking by debtors.

\section{Effects of Good Bankruptcy Laws}

Having observed the main goals of bankruptcy it is important to see what can be the impact of such reforms in terms of implementation. Majority of countries these days have quite comprehensive bankruptcy laws. But the true test is whether these are implemented in a right manner and what can be their impact on difference countries in real terms that can be measured. As such we also provide information on top 10 countries and the worst countries in implementation of bankruptcy reforms in the year 2015.

a) High number of Bankruptcies: However, the efficiency of a bankruptcy regime is in its adoption rate. If companies and creditors do not benefit from invoking a bankruptcy procedure, they will not use it. Hence, fewer bankruptcies will occur. This is what happens in countries with primitive bankruptcy regimes or with inefficient judicial systems. Countries like

${ }_{1}$ DTI/Insolvency Service, Productivity and Enterprise: Insolvency-A Second Chance, (Cm 5234, 2001); S Davies QC (ed), Insolvency and the Enterprise Act 2002 (Jordans, Bristol, 2003), p38-39 
Mozambique, Benin, Cameroon, Bangladesh, Nepal, Mali, Mongolia and Niger rarely use bankruptcy regimes. Their banks have an in-house debt recovery units which negotiate with customers directly. Rare cases where bankruptcy procedures are implemented are the liquidation of a subsidiary or a foreign company or a state owned firm. On the contrary, countries like Norway, Finland, Belgium, Sweden, Switzerland and Denmark have efficient bankruptcy regimes and have high incidences of bankruptcy filings.

b) High recovery rate: Efficient bankruptcy procedure must maximize the recovery rate for its creditors. Whether the bankruptcy law is effective or not can be seen with the recovery rate for the creditors. We gather information from doing business reports that ranks 189 economies on the ease of doing business. The last chapter deals with Insolvency. We provide information on based on the report of June 2015. In the Table you can find the list of top 10 countries that have highest recovery rate whereas you can also find the list of countries that have the lowest recovery rate. Further all the countries that have high recovery rates belong to developed World belonging to high income group countries mainly from Europe except for Japan and Singapore; they have well defined corporate bankruptcy procedures mainly a good reorganization procedure. While majority of the countries that have low recovery rates belonged to low income and lower middle income group there were some countries from High income group as well as upper middle income group as well. Most the countries that have low recovery rate have week bankruptcy procedures especially they lack in good reorganization procedures and in its implementation.

Table 1: Recovery Rates to Corporate Bankruptcy (Highest vs Lowest)

\begin{tabular}{|l|l|l|l|}
\hline Economy & Highest Recovery rate & Economy & Lowest Recovery rate \\
\hline Japan & 92.9 & Micronesia, Fed. Sts. & 3.2 \\
\hline Norway & 92.5 & Venezuela, RB & 6.4 \\
\hline Finland & 90.1 & Burundi & 7.2 \\
\hline Singapore & 89.7 & Cambodia & 8.3 \\
\hline Belgium & 89.3 & Ukraine & 8.3 \\
\hline Netherlands & 88.9 & Liberia & 8.4 \\
\hline United Kingdom & 88.6 & Suriname & 8.4 \\
\hline Slovenia & 88.2 & Dominican Republic & 9.2 \\
\hline Denmark & 87.8 & São Tomé and Príncipe & 9.3 \\
\hline Ireland & 87.7 & Sierra Leone & 10.8 \\
\hline
\end{tabular}

Source: Doing Business Survey (World Bank) ${ }^{1}$

\section{c) Faster resolution process}

Time is an important factor in determining the outcome of a bankruptcy procedure. Long and time taking proceedings inhibit the chances of debt recovery for creditors while creating unneeded tensions for all those involved. Also, as time passes, the company's assets lose their market value and remunerations of insolvency practitioners go up. As such some countries are despite having comprehensive bankruptcy laws are hesitant to use it as it may take 5 or 6 years to come up with any kind of resolution and for distressed company it implies loss of business, suppliers and customers which are likely to find a way to cease dealing with the distressed businesses.

Let us now see which are the fastest versus slowest countries for resolution to distress.

Table 2: Time to Bankruptcy (Fastest vs Slowest)

\begin{tabular}{|l|l|l|l|}
\hline Economy & Time in Years & Economy & Time in Years \\
\hline Ireland & 0.4 & São Tomé and Príncipe & 6.2 \\
\hline Japan & 0.6 & Cambodia & 6 \\
\hline
\end{tabular}

\footnotetext{
1 http://www.doingbusiness.org/
} 


\begin{tabular}{|l|l|l|l|}
\hline Canada & 0.8 & Ecuador & 5.3 \\
\hline Hong Kong SAR, China & 0.8 & Micronesia, Fed. Sts. & 5.3 \\
\hline Singapore & 0.8 & Burundi & 5 \\
\hline Slovenia & 0.8 & Gabon & 5 \\
\hline Belgium & 0.9 & Myanmar & 5 \\
\hline Finland & 0.9 & Niger & 5 \\
\hline Norway & 0.9 & Suriname & 5 \\
\hline Solomon Islands & 1 & Vietnam & 5 \\
\hline United Kingdom & 1 & & \\
\hline
\end{tabular}

Source: Doing business Survey (World Bank) ${ }^{1}$

\section{d) Lower Bankruptcy cost}

In Table 2, we notice that, in Norway and Singapore it costs about 1 percent and 3 percent of the value of the estate to resolve insolvency respectively. Whereas in Chad, Liberia it may almost cost as much as half the estate to go through formal bankruptcy. The heavy costs of bankruptcy procedures can discourage many countries from using formal bankruptcy procedures especially in poor countries. If the option of bankruptcy appears costly, ineffective and time consuming both debtors and creditors will tend to avoid it.

Table 3: Costs to Corporate Bankruptcy (Cost effective vs most costly)

\begin{tabular}{|l|l|l|l|}
\hline Economy & Cost (\% of estate) & Economy & Cost (\% of estate) \\
\hline Norway & 1 & Chad & 60 \\
\hline Singapore & 3 & Liberia & 42.5 \\
\hline Belgium & 3.5 & Sierra Leone & 42 \\
\hline Brunei Darussalam & 3.5 & Ukraine & 42 \\
\hline Japan & 3.5 & Dominican Republic & 38 \\
\hline Korea, Rep. & 3.5 & Marshall Islands & 38 \\
\hline Netherlands & 3.5 & Micronesia, Fed. Sts. & 38 \\
\hline New Zealand & 3.5 & Samoa & 38 \\
\hline Oman & 3.5 & Solomon Islands & 38 \\
\hline Denmark & 4 & Vanuatu & 38 \\
\hline & & Venezuela, RB & 38 \\
\hline
\end{tabular}

Source: Doing business Survey (World Bank)²

f) Survival of viable firms and Liquidation of non-viable firms and enforcement of contracts: Filtering of viable and nonviable firms is inherent for any bankruptcy law ${ }^{3}$. This filtering should be accurate otherwise efficient firms will be liquidated and inefficient firms allowed to continue which would result in further economic losses. Efficient judicial system can ensure a good filtering mechanism. While on the other hand if the judicial system is bad the debtors as well as

\footnotetext{
${ }^{1} \mathrm{http}: / / w w w . d o i n g b u s i n e s s . o r g /$

2 http://www.doingbusiness.org/

${ }_{3}^{3}$ Fisher and Martel (2004), study a sample of 303 Canadian firms in reorganization during 1977-1988. They find the type I errors (allowing a nonviable firm to continue) are likely to have four times more than the type Il errors (shutting down a viable firm).
} 
stakeholders will not trust and will not eventually use the system. This is common occurrence in countries with an inefficient bankruptcy regime or judicial system. In Table 4, we provide quality of judicial process (best vs worst).

Table 4: Quality of Judicial process

\begin{tabular}{|l|l|l|l|}
\hline Top 10 & $\begin{array}{l}\text { Quality of judicial processes } \\
\text { Index (0-18) }\end{array}$ & Worst 10 & $\begin{array}{l}\text { Quality of judicial processes } \\
\text { Index (0-18) }\end{array}$ \\
\hline Australia & 15.5 & Dibouti & 2.5 \\
\hline Singapore & 15.5 & Eritrea & 2.5 \\
\hline Macedonia, FYR & 15.5 & Timor-Leste & 2.5 \\
\hline United Kingdom & 15 & Equatorial Guinea & 3 \\
\hline Croatia & 15 & Myanmar & 3 \\
\hline Lithuania & 14.5 & Suriname & 3.5 \\
\hline China & 14.1 & Gabon & 4 \\
\hline Brazil - Rio de Janeiro & 14 & Iraq & 4 \\
\hline Austria & 14 & São Tomé and Príncipe & 4 \\
\hline Israel & 14 & South Sudan & 4 \\
\hline
\end{tabular}

Source: Doing business Survey (World Bank) ${ }^{1}$

\section{SURVEY OF REFORMS: LESSONS TO BE LEARNED FROM WORLDWIDE SUCCESSFUL PRACTICES}

Doing Business has noted that during the last 8 years, most of the OECD high income, Eastern European and Central Asian nation have implemented 126 bankruptcy reforms which include promotion of reorganization proceedings, simplification and acceleration of procedures, defining the roles of involved parties, out of court settlements, regulation and refinement of the standards of insolvency professionals and improving the rights of secured creditors.

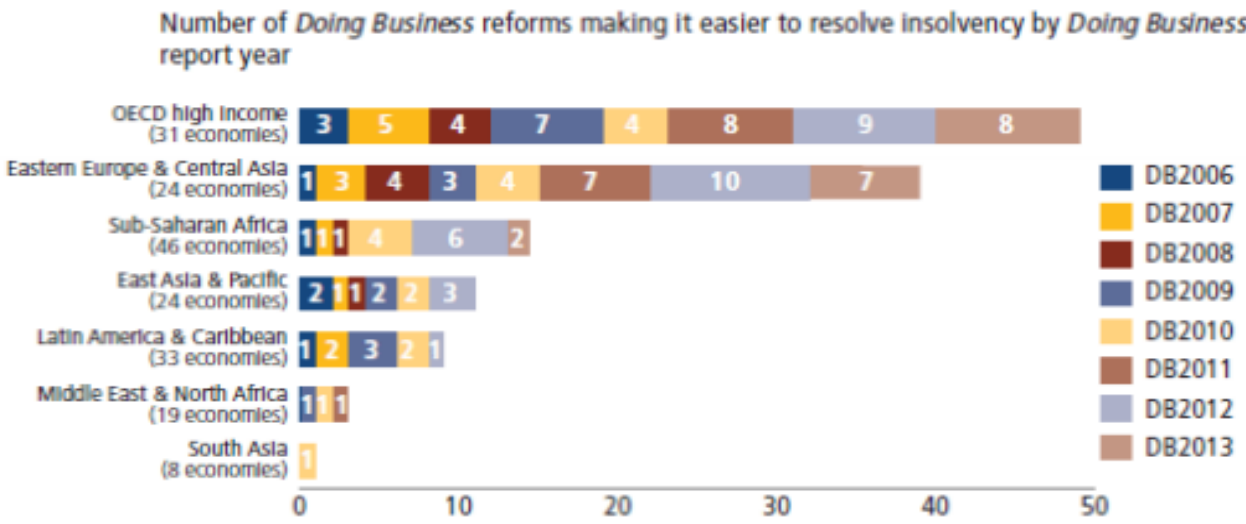

Figure1: Number of bankruptcy reforms introduced over the period of 8 years in different economies ${ }^{2}$

3.1. Empowering creditors by expanding their rights under bankruptcy: Finland's new bankruptcy act (120/2004) (iKonkurssilakiî) which came into effect on September 1, 2004, empowered the creditors by giving them the right to set up a creditors' committee that advises the administrator. This was based on an observation that involving creditors in the decision making process helped in maximizing their recoveries. Finland also improved the priority order for secured creditors, giving them a higher rank in the recovery process. According to doing business report (2006), Finland is one of

${ }_{1} \mathrm{http}: / /$ www.doingbusiness.org/

2 Source: World Bank Doing business reports 
the best countries for closing a business, yielding a high recovery rate of 89 cents on the dollar and also listed as one of most efficient country in resolving distress in terms of cost, time and recovery. Several other countries have followed the trend and consequently expanded the rights of creditors under bankruptcy. France for instance now allows the creditors' committee to vote on the reorganization plan and has also granted higher priority to post-petition claims in relation to secured creditor claims. This allows the company to obtain necessary financing in order to continue business operations. Expanding the rights of creditors has been the most popular reform in the last few years. All the reforms were introduced with the intention of improving recovery rates, speeding up the resolution process and enabling the survival of viable businesses. A recent study by Araujo et al. (2012) on Brazilian Bankruptcy procedure empirically demonstrated how increased creditor protection increased the recovery rate and reduced time to resolve distress. Brazilian bankruptcy procedures were enacted in 1945 and were found to be ineffective yielding a recovery rate of $0.2 \%$ while the averages for Latin American and OECD countries were $26 \%$ and $72 \%$, respectively. The bankruptcy priority rule proved penal for creditors as the order of priority was as follows: first the labor claims; second, tax claims; third, secured creditors and finally unsecured creditors' claims. Creditors were placed behind labor and tax claims. Hence, the amount remaining for creditors after payouts to the higher order claimants was typically inconsequential or even nil. Since this was known to creditors' exante, they increased the interest rate charged to firms.

This was the basic reason for the extremely high interest rate prevalent in Brazil before the new law. On June 9, 2005 the new bankruptcy legislation (Law 11,101/05) was introduced. Under these reforms, greater protection for secured creditors was ensured, leading to a significant reduction in the cost of debt and an increase in both short term and long-term debt. Consequently, in 2006, the creditor recovery rate increased to 12\% in Brazil, while the averages of Latin American and OECD countries remained stable ( $29 \%$ and $67 \%$, respectively). In subsequent years, the recovery rate registered a steady growth, reaching 17\% in 2009. Additionally, the standard time to close a business in Brazil has decreased from 10 to 4 years.

Box1: List of Countries that introduced reforms for empowering the rights of creditors in Bankruptcy: Korea, Romania, Slovakia, Czech Republic, Bulgaria, Philippines, South Africa, Kazakhstan, Slovak Republic, Italy, Ukraine, Samoa, Mexico, Russia, Saudi Arabia, St Kitts and Nevis, St Vincent, Moldova, Switzerland, Montenegro, Poland, Belarus, Australia, Germany, Cyprus, Bulgaria, France, Jamaica, China, Hungary, Denmark, Lithuania, Italy, Mozambique, Greece, Rwanda, Slovenia

Source: Doing business Survey (World Bank) (2005-2015)

3.2. Improved the likelihood of successful reorganizations: It has also been one of the most popular bankruptcy reforms. Several countries reforms have either introduced new reorganization procedure or streamlined the existing reorganization framework. The main aim being the survival of business and continuation of debtor's economic activity. For example: Many nations embraced bankruptcy laws with the intent of improving reorganization proceedings, setting time limits on judges to pass a reorganization plans, introduction of post filing financing and giving priority to loan repayments for companies under reorganization. Mexico amended its bankruptcy policies to allow easy accessibility to reorganization for creditors and debtors alike and at any stage of the insolvency process while Poland made amendments to its regimes to provide more security to creditors and for simplifying court proceedings. South Africa also adopted a new reorganization process in 2012 to help rehabilitate financially distressed firms. Switzerland on the other hand introduced a moratorium period to make the insolvency process easier. This gave time to debtors to prepare a reorganization agreement and also increased the participation of the creditors in this composition of agreement process.

Box2: List of Countries that introduced reforms for improving the likelihood of reorganization: Chile, Cyprus, Jamaica, Kazakhastan, Romania, St Vincent, Grenadines, Rwanda, Italy, Moldova, Belgium, Czech republic, Hungary, Japan, Republic of Korea, Latvia, Romania, Russia, Saudi Arabia, Serbia, Spain, Estonia, France, Kuwait, Mauritius, Philippines, Poland, Rwanda, Sierra Leone, Uruguay, Columbia, Czech Republic, Finland, Germany, Greece, Latvia, Mexico, New Zealand, Belarus, Germany, Greece, Kazakhstan, Lithuania, Moldova, Poland, Serbia, Slovak Republics, Spain, Uzbekistan 
Source: Doing business Survey (World Bank) (2005-2015) ${ }^{1}$

3.3. Speeding Court Procedures: Bankruptcy process should be easy, flexible and should provide quick and efficient solutions to the firm. As time is considered to be directly proportional to the cost of the procedure, adhering to a strict deadline, defined by laws, ensures a cost effective outcome. This is necessary so that stakeholders receive the maximum value out of the firm's assets and that the value of estate is not lost in lengthy and cumbersome bankruptcy proceedings. In US, these costs are found to consume a substantial part of bankruptcy estate (Altman, 1984; Altman and Vanderhoof, 1994). Once the insolvency process is triggered, a timely resolution becomes important, especially if the aim is to save the company. Longer delays are linked with the reduction of a firm's value, making it difficult for the firm to be sold as a going concern after insolvency proceedings. OECD countries have been found to have quicker insolvency proceedings with an average of 2 years where as South Asian countries have the longest insolvency proceedings averaging 4.5 years. Realizing the importance of this feature in insolvency, many countries have lately introduced strict time frames and deadlines in court for the resolution of distress. All this has been done with the objective of speeding the distress and resolution process so that the value of the firm can be preserved and maximized. Mohammad and Djankov (2009) states in many countries courts lack the infrastructure, training and expertise necessary to resolve commercial disputes in a timely manner. The capacity of the courts could be further strained with the increasing number of bankruptcy filings as such adequate intervention is necessary in reforms. To cope up with this stress many countries have introduced specialized bankruptcy courts to deal more efficiently with the distressed businesses and arrive at optimum solution in a timely manner. The United States has remarkably increased court efficiency with the online case management system that allows the bankruptcy judges to work from anywhere and consult any document from anywhere. It also allows signing of orders with the click of a mouse. This system was developed in 1999 and came into effect in all the states by 2005. Such innovative reforms can do wonders for accelerating the procedure and reducing associated costs.

Box3: List of Countries that introduced reforms for shortening time limits for insolvency proceedings: Chile, Romania, Vietnam, Moldova, Rwanda, Tanzania, Ukraine, Belarus, Georgia, Kazakhstan, Republic of Korea, Lithuania, Slovenia, Uganda, Uzbekistan, Estonia, Georgia, Latvia, Saudi Arabia, Serbia, Spain, United Kingdom, Albania, Lithuania, Russia, Tajikistan, Puerto Rico, Slovakia, US

Source: Doing business Survey (World Bank) (2005-2015)²

\subsection{Qualification, training and regulation of fees for insolvency practitioners:}

Insolvency practitioners whether an administrator, a receiver or a liquidator, play a vital role in the management of distressed businesses and resolution of default. Administrators and Receivers are not only responsible for drafting reorganization plans but also managing the company either solely or together with the incumbent manager. Liquidators are required to sell the assets of the non-viable business either piecemeal or as going concern. Many countries have realized the importance of the roles of insolvency practitioners and hence have launched reforms to ensure adequate business training and educational qualifications

In 2005, Chile built a framework to guarantee thorough reconnaissance by the bankruptcy commissioner and linking receivers' fees to the proceeds of the realized assets. The objective is to urge trustees to sell distressed assets quickly, augmenting returns. Administrators in numerous nations are paid on market proceeds. Doing so increases recovery rate by $20 \%$ on an average. Conversely, many nations compensate the administrators via either a monthly salary or time basis. Incidentally, the administrators earn a higher income by working longer and hence are not sufficiently motivated to speed up the process. Thus, regulation of fees could serve as an important reform for speeding the process and increasing the recoveries. According to Doing business report (2013), Poland has registered the greatest improvements since 2005 in the efficiency of resolving insolvency and costs were reduced by a third between 2007 and 2012 and the recovery rates were doubled. The main features of the reforms were: the establishment of qualification measures for insolvency practitioners

\footnotetext{
${ }^{1} \mathrm{http}: / /$ www.doingbusiness.org/reports/global-reports/doing-business-2016

2 http://www.doingbusiness.org/reports/global-reports/doing-business-2016
} 
for improving the quality of services and cost reduction by specifying a maximum limit on the remuneration of the administrators.

Box4: List of Countries that introduced reforms to regulate the profession of insolvency practitioners: Jamaica, Moldova, St. Vincent, Grenadlines and Vietnam, The Bahamas, Belarus, Ukraine, Kazakhstan, Poland, Slovenia, Uganda, Zambia, Belarus, Estonia, Lithuania, Russia, United Kingdom, Albania, Columbia, Malawi, Philippines, Russia, Cape Verde, Namibia, Mauritious, Tanzania, Australia

Source: Doing business Survey (World Bank) (2005-2015)

\subsection{Specialized Courts:}

In some countries specialized courts have been established to promote faster and less costly solutions for resolving default. A specialized court can improve insolvency procedures, because specialized judges have better training and more expertise and can make decisions swiftly. In absence of efficient judicial system or specialized courts it could prolong the default resolution process and courts will get overburdened. This was the case in Jamaica where insolvency cases have a 3 year backlog. One way to remedy this situation is to promote specialized courts which can offer resolutions quickly. As such in order to reform their bankruptcy proceedings the following economies have introduced specialized courts since 2005: (1) Malayasia established specialized courts in Kuala Lumpur that handle only foreclosure cases. This reduced the time span of proceedings from 2.25 to 1.5 years (2) Israel launched its economic department at the district court of Tel Aviv in 2010 (3) while Romania created its special courts in 2009.

Box5: List of Countries that introduced reforms to promote specialized courts: India, Romania, Chile, Latvia, Israel, Malaysia

Source: Doing business Survey (World Bank) (2005-2015)²

\subsection{Promoting out of court workouts:}

With the global financial crisis and surge in the number of the bankruptcy filings the courts were heavily burdened. One way to ease their burden is to introduce in the insolvency framework pre-negotiated reorganization plans which enable a negotiation between the creditors and debtors over their differences before approaching the court. In the United Kingdom, Bank of England advocated the use of London approach to achieve co-ordination and co-operation among the creditors to achieve a healthy rehabilitation for the already distressed firm . London Approach is an informal arrangement between the creditors, to allow a distressed firm to continue if it demonstrates the potential of being viable. It has no status in law and is carried out in a very private manner with no publicity at all. It is a voluntary mechanism initiated by the debtors who approach the banks for seeking assistance and fair treatment. London approach came into existence in the mid 1970's. This was the time when UK was facing industrial recession, high inflation and rising unemployment. In the absence of adequate rescue mechanisms at that time, a need emerged for saving the firms from financial troubles (Slatter, 1984:254). The Bank of England initiated a series of discussions with the other banks to promote this approach. The main objective was to ensure that a potentially viable firm should not be terminated solely because of conflicts between creditors. "Our aim is to break log-jams and to seek a solution which represents an acceptable promise for those concerned. In other words, we act as an 'honest broker'. It has been defined by British Banker Association (1996:1) as, "[a] non statutory and informal framework introduced with the support of the Bank of England for dealing with temporary support operations mounted by banks and other lenders to a company or group in financial difficulties, pending a possible restructuring".

The bank's motives in initiating and advocating its usage have been described as threefold by Kent: First, London approach might minimize the losses to banks and other interested parties from unavoidable company failures by employing patient and coordinated workouts. Second, it avoids companies from being subjected unnecessarily to receivership or liquidation and preserves viable jobs and productive capacity wherever possible. The underlying objective was to create a means to

\footnotetext{
$1 \mathrm{http} / / /$ www.doingbusiness.org/reports/global-reports/doing-business-2016

2 http://www.doingbusiness.org/reports/global-reports/doing-business-2016
} 
support companies whose problems were generally thought to be curable through a period of financial rehabilitation. Third, London approach might prevent failure of attempts in providing financial support for companies because their bankers could not agree to the terms on which it would be provided. As the central bank, the Bank of England was concerned with the reputation of the financial community which suffered from time to time from accusations that it was not supporting the real economy.

These were the reasons behind Bank of England's vast support to this mission of corporate rescue. Since its inception it is believed to have successfully resolved over 150 cases. It is supposedly considered successful for large firms owing a large debt and having numerous banks as creditors where the number of banks varied from 6 to 106.

There were many reasons which motivated the companies to opt for London Approach as compared to other insolvency processes. The first and foremost important reason for applying assistance under this approach was that the company trusted its banks and felt free to seek consultancy from its own bank rather than seeking help from a stranger. The second reason could be attributed to the fact that this procedure was kept very secret and confidential and apart from the creditors, the general public did not come to know about it. This in return preserved a company's goodwill and did not result in the loss of clients or in creation of bad reputation (Cutlers and Summers, 1988). Third reason can be the costs involved in the process. The firms are supposed to be already distressed and hardly have any money to spare for the huge consultancy fees of the insolvency practitioners or other consultants. In London approach no fees was ever requisitioned or even expected as the Bank was glad to offer assistance to such firms. Moreover, problems related to information asymmetry and hold outs are also dealt with. All creditors share the pain on equitable basis. The secured creditors do not enforce upon their collaterals and participate in the 'standstill' process to avoid the collapse of the viable company. Also this mechanism makes extra financing available which meets the company's demands for capital influx. It has been noted that the 'London Approach' has been instrumental for large firms having multiple banks as lenders internationally or domestically. This approach has been imitated by many countries despite legal and cultural differences.

Box6: List of Countries that introduced reforms to promote out of court workouts: Croatia, Mauritius, Portugal, Spain, Italy, Philippines

Source: Doing business Survey (World Bank) (2005-2015)

3.7. Increased Transparency and information: Brown (1989) pointed out that out of court workout is always successful in the presence of single creditor as information is considered symmetric. But in reality, it seems that the insiders are better informed than the outsiders and have better knowledge about the assets and liabilities of the company, the ongoing firm value and the liquidation value. They can greatly harness this information to their advantage. Giammarino (1989) and Mooradian (1994) proclaim that creditors might opt for costly bankruptcy procedures if they observe asymmetries of information and develop distrust towards the insiders. Thus, the vicious loop of asymmetric information spoils any chances of private agreement between debtors and creditors. Serbia in 2011/12 increased the transparency of the insolvency system by introducing a reform where all injunctions issued by the court are made publicly available via internet. Policy makers should introduce reforms that disseminate credible information to all stakeholders and hence promoting out of court workouts.

Box7: List of Countries that introduced reforms to increase transparency and information: Lithuania, Serbia

Source: Doing business Survey (World Bank) (2005-2015)²

\section{SOME OTHER REFORMS}

Here we provide some other reforms that are not so popular but some of them can be good for some countries. On the other hand, we discuss some reforms that should be considered revising. We provide the list of some of these reforms:

\footnotetext{
1 http://www.doingbusiness.org/reports/global-reports/doing-business-2016

$2 \mathrm{http}$ ://www.doingbusiness.org/reports/global-reports/doing-business-2016
} 
4.1 Auction approach: Baird in 1986 put forward a scheme of auction for the resolution of default. He believed that this kind of approach will prevent any unnecessary costs and reduce the time and money spent on negotiation process. According to him formal reorganization procedure should be rescinded and replaced by a mandatory sale procedure based on competitive auction based approach. The firm will be sold to highest bidder; cash would be collected and distributed amongst various claimants based in absolute priority order. This also resolved any conflicts amongst various categories of claimants. The highest bidder becomes the owner and is responsible to decide whether to continue business operations or to shut down or whether to retain the old management or to replace them. According to Baird (1986) and Easterbrook (1990) the auction based approach is a real sale of assets of the company and would provide more accurate estimate about the value of the firm than the court based hypothetical valuation procedures. Baird and Morrison (2001) further demonstrate that auction based approach also resolves asymmetry of information between the insiders (management) and outsiders (potential buyers). This is because managers have incentives to make credible information available to preserve the firm as going concern and retain their employment.

Sweden has effectively used auction based approach to resolve financial distress. All bankruptcy filings are resolved through auction based system. The winning bidder decides if the firm should be liquidated or the business should be continued. The auction is done in the presence of court appointed trustee, the management and shareholders lose their control rights. Despite successful empirical research that compares the efficiency of US chapter 11 vs Swedish auction based approach, there is still an ongoing debate on the merits of auction based system. As such, many countries have been reluctant in embracing such an approach for resolution of default. Mauritius embraced a new reform in 2007, under which land and buildings can be sold at private auction. Before asset sales was a tedious process and took place through "sale by levy" and failed to realize the assets' market value.

Box7: List of Countries that introduced reforms to introduce asset sales via auction: Mauritious, Saudi Arabia, Uzbekistan, Macedonia, Georgia, Belarus, Armenia

Source: Doing business Survey (World Bank) (2005-2015)1

4.2. Debt Equity Swaps: In 2012, German insolvency law introduced debt equity swaps for the viable companies where the creditors could directly participate in the insolvency proceedings and can swap the debt by equity. In debt equity swap, existing claims are exchanged for equity which cancels out a company's debt. As the company is liberated of debt it can emerge out of insolvency proceedings and can resume normal business operations. Thus, introducing this reform can first benefit the struggling company to emerge out of insolvency; second it can save the costs spent on paying the insolvency administrator fees, and lastly it allows the creditors to participate in the reorganization of the business and giving them control to make business decisions. Along the lines of Germany, Ukraine also adopted a new insolvency framework in 2012/2013 and introduced debt equity swaps for promoting reorganization of businesses. However, this new framework still needs to be subjected to empirical analysis before the viability of its efficiency can be determined with certainty.

Box8: List of Countries that introduced reforms to introduce debt equity swaps: Germany, Ukraine, Slovenia

Source: Doing business Survey (World Bank) (2005-2015)

\section{Box9: List of Countries that introduced reforms to encourage early filings}

Source: Doing business Survey (World Bank) (2005-2015)

4.3. Encouraging early filings to promote rescue: Debtors should not wait too long to apply for protection under bankruptcy procedure. The law should allow debtors to file for reorganization when financial distress is imminent rather than waiting for them to get bankrupt. The policy makers should encourage early filing so that business can seek timely solution and to expand the ground on which companies suffering from financial distress can file for protection under reorganization proceedings. In 2008/09, Poland and Estonia expanded the grounds for the companies to file for reorganization. The distressed companies that are on the verge of bankruptcy can file for protection and restructure their

\footnotetext{
1 http://www.doingbusiness.org/reports/global-reports/doing-business-2016

2 http://www.doingbusiness.org/reports/global-reports/doing-business-2016
} 
debts and restore profitability. Similar amendment was made by France under the safeguard "sauvegarde" procedure allowing and encouraging the firms to apply for court protection before they have become bankrupt. Kuwait and Philippines also implemented the use of pre-insolvency procedures to promote rescue.

4.4. Use of internet and authenticated professional platforms to sell assets or post decisions: The use of technology should be taken advantage of. Internet has become an integral part of the personal and professional life for billions of people. The information can be sent and shared in seconds with millions of people. Innovative platforms can be built online to promote quicker sale of assets under liquidations, photographs of such assets with detailed description of costs could be posted online. Businesses can be sold as going concerns as well, if they find appropriate buyers. Bidding system could be activated so that the business is sold to the highest bidder. Few countries have launched such innovative reforms. Croatia had launched a website called "Judges Web", where the court posts information on decisions in bankruptcy case and also announcement for asset sales. More countries can join the league and take advantage of internet.

4.5. Opportunity to start afresh: The penalty provisions in bankruptcy law that punish the entrepreneur and dampen their entrepreneurship spirit should be seriously considered a subject for revisions. Studies in the United States have shown that entrepreneurs try several business ideas before succeeding. Failure due to mistake, bad decision or innovation should not be punishable. Sometimes this failure could be attributed to mere bad luck or circumstantial or because of bad state of economy. In Greece bankrupt entrepreneurs lose their trading license while in Lithuania they may face criminal penalties even in the absence of fraud. In several other countries they can be barred from taking director positions. Punishing fraud is justified but punishing failure is not justified. Some countries have already moved on to abolishing such penalties. The United Kingdom with the Enterprise Act of 2002 removed automatic penalties on bankrupt debtors. Any provisions in bankruptcy law that discourage entrepreneurship should be considered for revision but at the same time faulty managers responsible for fraud and eventual bankruptcy should not be pardoned. Bankruptcy laws should facilitate towards the distinction between faulty managers and competent managers. Primarily, competent managers whose failure is attributed to unavoidable circumstances (misfortunes, natural calamities, external environment) should not be sanctioned by law. On the other hand, faulty managers who destroy the value of the company by recklessly undertaking risky projects and putting the creditor's money at stake should be held liable for sanctions. These sanctions can be pecuniary or non-pecuniary depending on the country in which the sanctions take place.

Easy accessibility of the procedure vs liabilities for frivolous filings: The advantage of an early initiation can be redeemed only if it is easily accessible by the stakeholders and is less restrictive of its demands. This means that the firms which have substantial assets still have a fair chance of resurrection, provided that the procedure is initiated at the right time. However, this easy accessibility can be fatal as it can generate opportunistic behaviour on the part of the companies which can strategically decide to default, as part of their business strategy thus exploiting this vulnerability of the bankruptcy system. The case of Texaco (a US based Corporation) Bankruptcy Filing is a brilliant illustration of an unorthodox adoption of Chapter 11 by an organization as a survival mechanism.

\section{CONCLUSION}

As the global economy promotes entrepreneurship, new businesses will emerge. Some may succeed while some will inevitably fail. However, the policymakers should not only concern themselves with promoting new businesses and creating new jobs and but also create efficient frameworks for reviving viable existing businesses and preserving jobs. Resolution of financial distress should be easy, flexible and should provide quick and efficient solutions to the distressed firms. As time is considered to be directly proportional to the cost of the procedure, adhering to a strict deadline, defined by laws, ensures a cost effective outcome. This is necessary so that stakeholders receive the maximum value out of the firm's assets and that the value of estate is not lost in lengthy and cumbersome bankruptcy proceedings.

One of the reasons companies fall into distress is often attributed to the faulty managerial behaviour and excessive risk taking. By monitoring the activities of the managers and keeping their risk taking activities under control, bankruptcy laws within the specific countries can, ex ante, protect the creditor claims and avoid imminent bankruptcies. These laws should be reformed and designed with the intent of not only identifying the faulty management but also with the power to penalize them. Although a certain level of risk is associated with all businesses activities but excessive risk taking for the realization of personal gains should not be promoted at any cost. 
The presence of formal bankruptcy procedures is existent in every country, but very few firms seek their assistance. In practice, the formal bankruptcy procedures for resolving financial distress are complex and cumbersome. A successful insolvency framework is constituted by not only exhaustive laws and regulations but also encompasses effective implementations of established practices by competent and trained professionals. Such reforms should include the creation of specialized bankruptcy courts, acceleration of insolvency proceedings, regulation of the profession of insolvency practitioners, giving equitable rights to creditors to participate in proceedings, providing breathing space to distressed debtors to formulate a reorganization plan, testing the viability of businesses, using internet technology for dissemination of information, providing easy accessibility to debtors, helping viable businesses survive and allocating the resources from unviable businesses to more profitable and viable ventures. Many a times, the effects of reforms are not immediately evident and may take time before it starts producing empirical data for research and validation. An absence of instant results should not discourage economies from adopting further reforms. The economies should invest in more quantifiable research to test the impacts of such reforms and should work towards innovation for the continued improvement of existing insolvency frameworks. It is important to understand that one reform could be highly successful in one country but may show unimpressive results in another. It is interesting to note that what would work for rich countries might not work for developing countries or struggling economies and vice versa. So to answer the question whether innovative reforms can resolve financial distress efficiently, we would like to conclude by suggesting that it certainly is possible given that policy makers develop and execute reforms with a deep understanding of the challenges of the economic, political and social environment of their specific countries and utilize technology and innovative measures to achieve the objective of creating and maintaining an efficient and harmonious insolvency framework and foster a healthier and viable economic and financial climate in the country.

\section{REFERENCES:}

[1] Aghion P., Hart O., and Moore J. [1992], "The Economics of Bankruptcy Reform", Journal of Law, Economics and Organizations, Vol. 8., pp. 523-546.

[2] Altman E. I. [1984], "A Further Empirical Investigation of the Bankruptcy Cost Question", Journal of Finance, Vol. 39, No. 4, pp. 1067-1089.

[3] Altman, Edward I. Vanderhoof, I. [1994]. "Losses to Bankrupt Firms' Bondholders," Financial dynamics of the Insurance Industry, editor, Irwin, (Ch 7).

[4] Amin, Mohammad \& Djankov, Simeon, [2009]. "Democracy and reforms," Policy Research Working Paper Series 4835, The World Bank.

[5] Araujo, A., R. Ferreira, and B. Funchal [2012]. "The Brazilian Bankruptcy Law Experience". Journal of Corporate Finance 18 (4), 994-1004.

[6] Baird, D. G. [1991]. "The Initiation Problem in Bankruptcy" International Journal of Law and Economics, 11(2), 223-323.

[7] Baird Douglas G. [1986]. "The Uneasy Case for Corporate Reorganization," Journal of Legal Studies, 15, 127147.

[8] Baird Douglas G. [1987]. "A World without Bankruptcy", Law and Contemporary Problems, Vol. 50, 173-193.

[9] Baird D.G., and Morrison E. R. [2001], "Bankruptcy Decision Making", Journal of Law, Economics and Organization, Vol. 17, No. 2, pp. 356-372.

[10] Baird, D. G. \& Rasmussen, R. K. [2003]. "Chapter 11 at Twilight," The Chicago Working Paper series Index at www.law.uchicago.edu/Lawecon/index.

[11] Bebchuk L.A. [1988], "A New Approach to Corporate Reorganizations", Harvard Law Review, Vol. 101, pp. 775804.

[12] Bebchuk L.A.[1998], "Chapter 11", The New Palgrave Dictionary of Economics and the Law, Vol. 3, pp. 219224.

[13] Bebchuk L.A. [2000], "Using Options to Divide Value in Corporate Bankruptcy", European Economic Review, Vol. 44, pp. 829-843.

[14] Blazy, R., Martel, J. and Nigam, N., [2014], "The choice between informal and formal restructuring: The case of French banks facing distressed SMEs", Journal of Banking and Finance, Vol 44, pp 248-263.

[15] BOUGHANMI A., NIGAM N. [2013], "A Review of Bankruptcy Literature: A Law and Finance Approach", Revue Organisation Responsable (ROR), Regulating CSR: southern and northern perspectives, 8, 63-74. 
[16] BOUGHANMI A., NIGAM N. [2016], "Law and Finance", Encyclopedia of Law and Economics, Springer New York, May.

[17] BOUGHANMI A., NIGAM N. [2017], "Can innovative reforms and practices efficiently resolve financial distress?" Journal of Cleaner Production, Volume 140, Part 3, pp 1860-1871.

[18] Bris, Arturo, Ivo Welch and Ning Zhu [2006]. "The Costs of Bankruptcy: Chapter 7 Liquidation versus Chapter 11 Reorganization," Journal of Finance, 61, 1253-1303.

[19] Brouwer, M. [2006], "Reorganization in US and European Bankruptcy Law", European Journal of Law and Economics, 22, 5-20.

[20] Brown, David T. [1989]. "Claimholder Incentive Conflicts in Reorganization: The Role of Bankruptcy Law," Review of Financial Studies, 2, 109-123.

[21] Bulow, Jeremy I. and John B. Shoven [1978]. "The Bankruptcy Decision," Bell Journal of Economics and Management Science, 9, 437-456.

[22] Carapeto, Maria [2005]. "Bankruptcy Bargaining with Outside Options and Strategic Delay," Journal of Corporate Finance, 11, 736-746.

[23] Chatterjee, Sris, Upinder S. Dhillon and Gabriel G. Ramirez [1995]. "Coercive Tender and Exchange Offers in Distressed High-yield Debt Restructurings: An Empirical Analysis," Journal of Financial Economics, 38, 333360.

[24] Claessens, Stijn and Leora Klapper [2005], "Bankruptcy around the World: Explanations of its Relative Use," American Law and Economic Review, 7 (Spring): 253-83.

[25] Couwenberg, O. [2001]. "Survival Rates in Bankruptcy System: Overlooking the Evidence," European Journal of Law and Economics, 12, 253-273.

[26] Cutler, D.M. and L.H. Summers [1988], "The Costs of Conflict Resolution and Financial Distress: Evidence from the Texaco-Pennzoil Litigation," Rand Journal of Economics, Vol. 19, 157-72.

[27] Denis, Diane K. and Kimberly J. Rodgers [2007]. "Chapter 11: Duration, Outcome and Post-Reorganization Performance," Journal of Financial and Quantitative Analysis, 42, 101-118.

[28] Djankov S., O. Hart. C. Mc Liesh, A. Shleifer [2008]. "Debt Enforcement around the World," Journal of Political Economy, 116, 6, 1105-1149.

[29] Easterbrook F.H. [1990]. "Is Corporate Bankruptcy Efficient?", Journal of Financial Economics, Vol. 27, pp. 411418.

[30] European Commisson [2012]. "Eurobarometer Survey on Entrepreneurship" available online http://ec.europa.eu/enterprise/policies/sme/facts-figures-analysis/eurobarometer/

[31] Fisher, Timothy C.G., \& Martel Jocelyn [1995]. "The Creditors' Financial Reorganization Decision: New Evidence from Canadian Data", Journal of Law Economics and Organization, 11, 112-126.

[32] Fisher, Timothy., \& Martel, Jocelyn [2004]. "Empirical Estimates Of Filtering Failure In Court-Supervised Reorganization". Journal of Empirical Legal Studies, 1(1), 143-164.

[33] Franks, Julian R, and Kjell G. Nyborg [1996]. "Control Rights, Debt Structure and the Loss of Private Benefits: The Case of the UK Insolvency Code," Review of Financial Studies, 9, 1165-1210.

[34] Franks, Julian R. and Walter N. Torous [1989]. "An Empirical Investigation of U.S. Firms in Reorganization," Journal of Finance, 44, 747-769.

[35] Gertner, Robert and David Scharfstein [1991]. "A Theory of Workouts and the Effects of Reorganization Law," Journal of Finance, 46, 1189-1222.

[36] Giammarino, Ronald M. [1989]. "The Resolution of Financial Distress," Review of Financial Studies, 2, 25-47.

[37] Gilson, Stuart C. [1990]. "Bankruptcy, Boards, Banks, and Blockholders: Evidence on Changes in Corporate Ownership and Control When Firms Default," Journal of Financial Economics, 26, 355-387.

[38] Gilson, Stuart C. [1997]. "Transactions Costs and Capital Structure Choice: Evidence from Financially Distressed Firms," Journal of Finance, 52, 161-196.

[39] Gilson, Stuart C., Kose John, and Larry H. P. Lang [1990]. "Troubled Debt Restructurings: An Empirical Study Private Reorganization of Firms in Default, Journal of Financial Economics, 27, 315-353.

[40] Grossman, Sanford J. and Oliver D. Hart [1981]. "The Allocational Role of Takeover Bids in Situations of Asymmetric Information (in the Allocation Role of the Stock Market)," Journal of Finance, 36, 253-270.

[41] Harris, Milton and Artur Raviv [1991]. "The Theory of Capital Structure," Journal of Finance, 46, 297-355.

[42] Hart, Oliver, [1995]. "Firms, contracts and financial structure", Clarendon Press. 
[43] Haugen R.A., L.W. Senbet [1978]. "The Insignificance of Bankruptcy Costs to the Theory of Optimal Capital Structure", Journal of Finance, Vol. 33, 383-393.

[44] Hege U. [2003]. "Workouts, Court-Supervised Reorganization and the Choice between Private and Public Debt" Journal of Corporate Finance, Vol. 9 (1) 233-269.

[45] Hoshi, Takeo, Anil Kashyap \& David Scharfstein [1990]. "The Role of Banks in Reducing the Costs of Financial Distress in Japan," Journal of Financial Economics, 27, 67-88.

[46] Jensen, Michael C. [1989]. "Active Investors, LBOs, and the Privatization of Bankruptcy," Journal of Applied Corporate Finance, 2, 35-44.

[47] Jensen, Michael C. [1991]. "Corporate Control and the Politics of Finance," Journal of Applied Corporate Finance, 4, 13-33.

[48] Mooradian, Robert M. [1994]. "The Effect of Bankruptcy Protection on Investment: Chapter 11 as a Screening Device," Journal of Finance, 49, 1403-1430.

[49] Morrison, Edward R. [2007]. "Bankruptcy Decision making: An Empirical Study of Continuation Bias in Chapter 11," Journal of Law and Economics, 50(2), 381-419.

[50] Philip R. Wood [1995]. "Principles of International Insolvency Law", London Sweet \& Maxwell, London.

[51] Pulvino, Todd C. [1999]. "Effects of Bankruptcy Court Protection on Asset Sales," Journal of Financial Economics, 52, 151-186.

[52] Roe, Mark J. [1983]. "Bankruptcy and Debt: A New Model for Corporate Reorganization," Columbia Law Review, $83,527$.

[53] Roe, Mark J. [1987]. "The Voting Prohibition in Bond Workouts," Yale Review Journal, 97, 232-279.

[54] Shleifer, Andrei and Robert W. Vishny [1992]. "Liquidation Values and Debt Capacity: A Market Equilibrium Approach," Journal of Finance, 47, 1343-1366.

[55] Slater, S., [1984], "Corporate Recovery: A guide to turnaround management", Harmondsworth, UK: Penguin Books.

[56] Thorburn, Karin S. [2000]. "Bankruptcy Auctions: Costs, Debt Recovery, and Firm Survival," Journal of Financial Economics, 58, 337-368.

[57] Webb D.C. [1987]. "The Importance of Incomplete Information in Explaining the Existence of Costly Bankruptcy," Economica, august, 54, 279-288.

[58] Weiss, Lawrence A. and Karen Hopper Wruck [1998]. "Information Problems, Conflicts of Interest, and Asset Stripping: Chapter 11's Failure in the Case of Eastern Airlines," Journal of Financial Economics, 48, 55-97.

[59] White, Michelle J. [1990]. "Bankruptcy Liquidation and Reorganization," in Handbook of Modern Finance, 2nd Ed., Dennis E. Logue, ed. Boston, Mass: Warren Gorham and Lamont, Inc., 37-1 - 37-49.

[60] White, Michelle J. [1994a]. "Does Chapter 11 Save Economically Inefficient Firms?" Washington University Review, 72, 1319.

[61] White, Michelle J. [1994b]. "Corporate Bankruptcy as a Filtering Device: Chapter 11 Reorganization and Out-ofCourt Debt Restructurings," Journal of Law Economics and Organization, 10, 268-295.

[62] World Bank [2006]. "Closing a business", Doing business in 2006: Creating Jobs, 67-76.

[63] World Bank [2008]. "Closing a business", Doing business report, pp 54-58

[64] World Bank [2013]. "Closing a business", Doing business report, Smarter Regulations for Small and MediumSize Enterprises, pp 94-97

[65] Wruck, Karen Hopper [1990]. "Financial Distress, Reorganization, and Organizational Efficiency," Journal of Financial Economics, 27, 419-444. 